\title{
Ownership Structure and Enterprise Restructuring in Six Newly Independent States
}

\author{
Simeon Djankov \\ World Bank
}

\begin{abstract}
Journal of Economic Literature Classification Numbers: L2, P0
\end{abstract}
This study investigates the relation between ownership structure and enterprise restructuring in six Newly Independent States. We document the changing pattern of ownership in 960 privatized manufacturing companies in the 1995-97 period. There are large differences in the ownership structure across countries, and these differences seem to be determined by the type of privatization methods pursued. We show that foreign ownership is positively associated with enterprise restructuring at high ownership levels (above $30 \%$ of total shares). In contrast, the relation between manager ownership and enterprise restructuring is non-monotonic, positive at low (below 10\%) or high (above 30\%) stakes, but negative at intermediate levels. Finally, we show that ownership by outside local investors or the state is not significantly correlated with restructuring.

I am grateful to Harry Broadman, Gregory Jedrzejczak, Leonid Koryukin, Vladimir Kreacic, Arlene Mirsky, John Nellis, Gerhard Pohl, and Randi Ryterman, Robert Stuart (the editor), and two anonymous referees for helpful suggestions. The views expressed are personal and should not be attributed to the World Bank. Correspondence: sdjankov@worldbank.org; tel: 202-473-4748. 


\section{Introduction}

The literature on ownership structure and enterprise restructuring during the transition from plan to market consists primarily of studies based on evidence from Central European and Baltic countries. ${ }^{1}$ This is hardly surprising since these countries entered the liberalization process early and have been subject to significant research interest due to their imminent accession to the European Union. At the opposite, little research has been devoted to Newly Independent States (NIS) countries. ${ }^{2}$ Reasons for this neglect abound. In the early years of transition, most NIS countries were struggling to create their government structures and legislation after decades of political control from Moscow. Some were involved in either civil wars or border conflicts. Lastly, the absence of established systems of data collection by government agencies precluded rigorous empirical work.

Most NIS enterprises entered the reform period from a different set of initial conditions when compared to enterprises in Central and Eastern Europe. For example, NIS countries were more highly integrated in their input and output markets than the Central European countries. ${ }^{3}$ Central-planning bureaucrats arranged cooperation between enterprises even if they were located within a few miles from each other across republican borders. More importantly, all international trade was channeled through foreign trade organizations in Moscow. The dependence on central distribution meant that enterprise managers were never involved in marketing their products abroad, or producing goods to meet international standards and technical requirements. Finally, the privatization process in most NIS countries favored incumbent managers, unlike most other transition economies where mass privatization and sales to outsiders were pursued rigorously. These differences suggest that the relation between ownership structure and enterprise restructuring in the NIS may be worth investigating, as many of the stylized facts documented for enterprises in more advanced transition economies may not hold true.

In this paper we investigate the relation between ownership structure and enterprise restructuring in the NIS, using detailed survey data from Georgia, Kazakstan, the Kyrgyz Republic, Moldova, Russia, Ukraine. The surveys were conducted by World Bank consultants as part of private sector reviews in late 1997 and early 1998. Excluded from the survey are enterprises in the remaining six NIS countries (Armenia, Azerbaijan, Belarus, Tajikistan, Turkmenistan, Uzbekistan) for which data were not available. We choose to study the link between ownership structure and enterprise performance in the NIS because there has been little previous research on that issue, and because sufficient time has already past since privatization took place. The latter implies that we may be able to uncover discernible patterns which were absent in earlier data sets.

We document the changing pattern of ownership in 960 privatized manufacturing companies across the six countries in the 1995-97 period. There are 
large differences in the ownership structure across countries, and these differences seem to be determined by the type of privatization methods pursued. In particular, enterprises in countries where the privatization programs favored incumbent managers (Georgia and Ukraine) ended up with large ownership by managers ( $53.6 \%$ and $46.2 \%$ of total ownership on average) by 1997 . Enterprises in countries which chose equal opportunity mass privatization as their primary privatization method (Kazakstan and the Kyrgyz Republic) have the highest ownership shares of outside investors ( $37 \%$ and $21.2 \%$ respectively).

We show that foreign ownership is positively associated with enterprise restructuring at high ownership levels (above $30 \%$ of total shares). In contrast, the relation between manager ownership and enterprise restructuring in non-monotonic, positive at low (below $10 \%$ ) or high (above 30\%) stakes, but negative at intermediate (between $10 \%$ and $30 \%$ ) levels. We also show that ownership by outside local investors or the state is not significantly correlated with restructuring. Finally, employee ownership is beneficial to labor productivity growth at low ownership levels, but becomes insignificant at higher levels, and for the other two restructuring measures.

The paper is organized as follows. Section 2 reviews some of the existing literature on the effect of ownership structure on firm restructuring, drawing on studies from both mature and transition economies. Section 3 details the data used and the methodology for its collection. Section 4 provides statistics on changes in ownership structure. Section 5 uses regression analysis to study the relation between ownership structure and enterprise restructuring, using three alternative measures of restructuring (labor productivity growth, asset sales, minor renovations), and investigates whether this relation is monotonic for different types of ownership. Section 6 concludes.

\section{Ownership Structure and Firm Restructuring}

The increasing availability of large data sets on firms listed on the stock market over the last twenty years has greatly expanded the empirical literature examining the effects of different types of ownership structures on corporate restructuring. Most of these studies have focused on US companies, relatively little work has been done in developing or transition economies. We outline below the stylized facts that have been uncovered in the empirical literature todate, while cautioning the reader that these facts may not apply to enterprises in transition economies. It is nevertheless useful to consider the evidence from developed countries since it provides a benchmark for the likely effects of ownership structure once it has reached an equilibrium level and changes are only at the margin.

Managerial Ownership. The empirical work on the association between managerial ownership and corporate restructuring dates back more than sixty years to Berle and Means (1933). They contend that diffuse ownership yields significant power in the hands of managers whose interests do not coincide 
with the interest of shareholders. As a result, corporate resources are not used for the maximization of shareholders' value. Studies for the US (e.g., Morck, Shleifer and Vishny, 1988; McConnell and Servaes, 1990) find a non-linear relation between managerial ownership concentration and corporate restructuring.

Some compelling evidence on profit-diminishing managerial behavior comes from acquisition announcements in the US. Many studies show that bidder returns on the announcement of acquisitions driven by managers are often negative (Roll (1986) surveys the evidence). Another strand of the literature focuses on managers directly threatened with the loss of private benefits of control. These are studies of management resistance to takeovers. Walkling and Long (1984) find that managerial resistance to value-increasing takeovers is less likely when top managers have a direct financial interest in the deal either through share ownership or golden parachutes. In contrast, Malatesta and Walkling (1988) find that firms which have experienced challenges to management control, the adoption of devices to make takeovers costly, reduce shareholders' wealth. Finally, there is some indirect evidence on the importance of management entrenchment. Johnson et al. (1985) find that sudden executive deaths - in plane crushes or from heart attacks - are often accompanied by increases in the share price of companies these executives managed. The price increases are largest for major conglomerates, whose managers built vast empires without returning to shareholders.

Employee Ownership. This category of ownership has not been extensively studied. It has been argued that unionized employees more likely seek control of a firm, but the actual monitoring role of employee owners has not been well-documented. The exception is Blasi and Kruse (1995) which reviews the evidence concerning the effects of employee ownership from over 50 country- or industry-specific studies. The study finds mixed effects on performance - while worker-owners display higher job satisfaction and motivation, they are not more productive than workers who do not own equity in their companies. Blasi, Conte, and Kruse (1996) use corporate data for the United States to find that employee ownership is associated with improved firm performance only in small-size companies. We use the available evidence to argue that employees, like small shareholders, may be less able (and face little incentive) to monitor firm restructuring.

Individual Ownership. Shleifer and Vishny (1986) argued that individual block-owners have strong incentive to monitor management because of their non-diversifiable holding in the corporation. Consistent evidence is reported by Friend and Lang (1988) that the presence of individual block-holders forces management to use more debt for disciplinary purposes. Other studies (Coase, 1988; Demsetz and Lehn, 1985) argue, however, that any relation between individual ownership concentration and firm restructuring may be spurious. While greater ownership concentration results in stronger incentives to monitor, the expected gain from active monitoring and the costs of alternative ownership structures vary across firms. If transaction costs inhibiting investors 
from taking value-maximizing positions in firms are low each firm would have the "right" ownership structure and there may not be a relationship from ownership to restructuring. One thus needs to be cognizant of the two-way relation between individual ownership and restructuring.

Government Ownership. In case of state ownership, politicians will likely have interests in addition to maximizing enterprise restructuring, such as preserving jobs. There is general evidence that state-owned firms are less efficient than privately owned firms are (Megginson et al., 1994). In the case of East Asia, however, it has been argued that the state has had a beneficial role in stimulating long-term development (World Bank, 1994). It has done so by offering special treatments including protection from import competition, offers of government contracts, or participation in subsidized export promotion program, which may also lead to increased short-term restructuring. It is thus not clear a priori what the relation is.

Outside Ownership. Better restructuring of firms may be due to signaling and special abilities of outside owners. Some corporate outside investors, for example, may be more able to evaluate firms - based on their better information. Other corporate investors may be better owners as they may have access to technology or know-how not available to the firm (e.g., foreign investors) or they may have special monitoring skills (e.g., trade creditors which are owners), which may raise the valuation or profitability of the firm. On the other hand, the presence of corporate owners may harm the firm's restructuring since these owners may collude with incumbent management to expropriate wealth from other shareholders. This argument is consistent with the observation by Jensen (1993) that the board of directors of US firms often consists of representatives of other corporations and reacts too slowly in removing bad management.

Large outside owners in general have opportunities to expropriate value, particularly when the minority shareholders are not well protected. When financial institutions are large owners, conflicts of interest are a further possibility of expropriation of minority shareholders. Commercial banks could face conflicts when they are large creditors of the firms in which they hold equity stakes. There can be direct dilution of other equity holders for the benefit of the bank, for example, through higher lending spreads. Financial institutions related to banks may also have the interests of the bank as a creditor in mind when deciding in which company to invest and how to value a firm. Offsetting these effects can be the better monitoring of firms and their management by a financial institution when it has an equity stake. This can be because it then has more access to information and because it will have more interest in monitoring. Because the conflicts of interest and improved monitoring effects go in opposite direction, the net effect of financial institutions' ownership on the valuation of the firms and its profitability is unclear.

The evidence for transition economies is very scarce. A detailed survey of case study evidence (Carlin et al, 1995) shows, for a sample of Czech, Hungarian, Russian, and Bulgarian enterprises, that firms owned by foreign inves- 
tors perform best, but there is little difference between local insider (manager and employees) and outsider dominated firms. Frydman et al. (1997), using a large data set of Czech, Hungarian, and Polish enterprises, find that private firms outperform state-owned firms, but that outsider-dominated firms do not outperform insider-dominated firms. Smith et al. (1997) find that foreign dominated enterprises in Slovenia have the highest growth in value-added, while insider-controlled firms have a higher average growth when compared to firms controlled by outside local investors. Earle and Estrin (1997) and Linz and Krueger (1998) find no evidence of a robust relation between types of ownership and enterprise restructuring in Russia, using several alternative specifications. Similar conclusions are reached in Estrin and Rosevear (1998) for Ukrainian enterprises.

While indicative, the aforementioned studies on transition economies may be incomplete in their investigations of the relation between ownership structure and enterprise restructuring, since they do not look at evidence for non-monotonic correlation patterns. In most cases, this is due to the lack of appropriate data. The contribution of this study to the transition literature is that we explicitly test for the possibility of piecewise-linear associations.

\section{The Sample}

The empirical work on enterprise restructuring in the NIS has been constrained by the lack of firm-level data. In the six countries under investigation, only Russia and Ukraine maintained an uninterrupted industry census in the reform period. The data were, however, of limited use for empirical work due to the hyper-inflation during the early period (1992-94). The other four countries initiated independent industrial census in 1994-95. Those, however, covered only former state-owned enterprises. Frequently, enterprises which changed their ownership form and re-registered were also dropped from the data or treated as new entities. Furthermore, the census did not include detailed information on ownership types.

To avoid problems with quantitative data collected by national statistical offices, and to better understand the nature of qualitative changes, we utilize a survey methodology following on the pioneering work of Pinto et al (1993) and Carlin et al. (1995) in Central European transition economies, and Hendley et al. (1997) and Linz and Krueger (1998) in Russia. All surveys were designed as part of private sector reviews, conducted by World Bank consultants, and distributed to enterprise managers in their native language. The survey results were then processed simultaneously, to avoid possible biases. In each of the six countries, a number of enterprises - in total over two hundred - were visited by the author in the pilot phase of the surveys.

The sample was restricted to privatized manufacturing enterprises. We focus on manufacturing firms since those are likely to have experienced specific difficulties (output declines, loss of markets, need for quality upgrading) 
which are not characteristic of other firms. We also exclude state-owned enterprises from the analysis, since a large (and fairly consistent) literature comparing the restructuring of state-owned and privatized enterprises already exists (see EBRD, 1997 for a survey). Another strand of the empirical literature has examined the restructuring and ownership structure of new private enterprises (Konings, 1998). In contrast, the primary goal of this paper is to shed light on the relation between ownership structure and firm restructuring once a former state-owned enterprise is (at least partially) in private hands.

The samples contain different number of firms in each country (Table 1). The largest sample is for Russia - 682 enterprises, the smallest is for Ukraine 49 enterprises. Across the eight manufacturing industries surveyed, the largest number of enterprises (224) is in the Food and Beverage industry, while the smallest number (94) is in the Chemicals industry. The distribution of enterprises across sector is relatively even, ensuring the ability to control for sectors in the regression analysis in Sections 5 and 6. There is also sufficient sampling across regions to at least in part capture the behavior of enterprises in each country. ${ }^{4}$

The differences across countries are mostly due to data limitations - the Georgian, Kyrgyz, Moldovan, and Russian surveys were developed over the course of two years with substantial help from local consultants. The Kazak and Ukrainian surveys, on the other hand, originated as more limited exercises. In total, the study covers 960 manufacturing firms across the six countries. The data are not representative. The samples constitute a small share of the manufacturing firms in each country. The selection bias is, however, minimized whenever possible. Surveyed enterprises were drawn from larger samples of enterprise units. The latter lists typically came from business registry data. Enterprises were then sorted alphabetically (using the Slavic alphabet) by name and random draws were taken. The sample does not include firms located in the autonomous regions of Transnistria in Moldova and Abhasia in Georgia. While there is a possible selection bias and a small sample bias in the data, the insights of this study are less dependent on such deficiencies than, say, studies which estimate productivity growth of the economy.

The sample is unique in several dimensions. First, it is based on a consistent survey methodology to study ownership structure and enterprise restructuring across the six NIS countries. Second, it contains enterprises from different sectors and regions within a country thus allowing the researcher to control for the importance of sectoral and regional factors in firm restructuring. Finally, it covers a dynamic period in the transformation process when redistribution of ownership was rapidly taking place. This in turn enables us to document the evolution of ownership structure. 
Table 1

The Enterprise Sample By Sectors

\begin{tabular}{|c|c|c|c|c|c|c|c|}
\hline Country & Georgia & Kazakstan & Kyrgyz Rep. & Moldova & Russia & Ukraine & Total \\
\hline Metals & 16 & 6 & 5 & 14 & 61 & 4 & 106 \\
\hline Chemicals & 13 & 5 & 5 & 11 & 53 & 5 & 94 \\
\hline Machinery & 23 & 11 & 7 & 22 & 100 & 9 & 172 \\
\hline Wood \& Furniture & 5 & 4 & 5 & 8 & 97 & 2 & 121 \\
\hline $\begin{array}{l}\text { Construction } \\
\text { Materials }\end{array}$ & 7 & 8 & 8 & 16 & 102 & 6 & 147 \\
\hline Textiles \& Apparel & 14 & 12 & 19 & 24 & 98 & 11 & 178 \\
\hline Food \& Beverage & 42 & 14 & 25 & 33 & 101 & 9 & 224 \\
\hline Pharmaceuticals & 9 & 2 & 5 & 9 & 70 & 3 & 98 \\
\hline $\begin{array}{l}\text { Total Manu- } \\
\text { facturing }\end{array}$ & 129 & 62 & 79 & 137 & 682 & 49 & 960 \\
\hline
\end{tabular}

\section{Ownership Structure of NIS Firms}

In many NIS countries, the privatization process favored insiders either through management-employee buy-outs (MEBOs) or through voucher privatization with significant concessions to insiders (Table 2). Georgia was the only country which opted for voucher privatization with concessions to managers and MEBOs as the prevalent privatization methods. Ukraine started with MEBOs but later introduced a voucher scheme for a limited number of enterprises (also see Estrin and Rosevear, 1998). In contrast, Kazakstan and the Kyrgyz Republic initiated equal access voucher programs, but cancelled their second waves and turned to sales to outsiders and MEBOs respectively. In Russia, managers and employees were allowed to choose among three different privatization options. The vast majority of enterprises went for $51 \%$ insider ownership with the rest retained by the state or given to investment funds. Many subsequent privatization deals were struck directly with outside local investors or managers. Finally, Moldova combined a voucher program with sales to outsiders. Voucher holders could invest directly in companies or go through the investment funds. There were restrictions on the shares bought in each company by investment funds, although they could buy majority stakes in some companies. ${ }^{5}$

The methods of privatization chosen in each country determined to a large degree the ownership structure that evolved subsequently. In particular, enterprises in countries where the privatization programs favored incumbent managers (Georgia and Ukraine) ended up with large ownership by managers (53.6\% and $46.2 \%$ of total ownership on average) by 1997 . Enterprises in countries which chose equal opportunity mass privatization as their primary 
privatization method (Kazakstan and the Kyrgyz Republic) had high ownership shares of outside investors (37\% and $21.2 \%$ respectively). Enterprises in Moldova and Russia had more diversified ownership on average. This does not suggest, however, a pattern of dispersed ownership in any given firm. Rather, it is a consequence of the different privatization paths followed across groups of firms.

\section{Table 2}

Methods of Privatization

\begin{tabular}{lllll}
\hline Country & Sale to & Vouchers: & Vouchers: \\
& Outsiders & Equal Access & MEBOs \\
& & & \\
& & to Insiders
\end{tabular}

\begin{tabular}{lllll}
\hline Georgia & & Primary & Secondary \\
Kazakstan & Secondary & Primary & & \\
Kyrgyz Republic & & Primary & & Secondary \\
Moldova & Secondary & & Primary & \\
Russia & Secondary & & Primary & Tertiary \\
Ukraine & & Secondary & & Primary \\
\hline
\end{tabular}

Source: EBRD, 1997, table 5.7.

With the exception of Moldova where managers and employees owned approximately the same share in 1997 (18.3\% and 19.7\%), managers had accumulated significant stakes by buying out employees and state shares in the 1995-97 period. This pattern is particularly striking in Ukraine, where in two years managers amassed $46.2 \%$ of all shares on average. The relevant statistics may be, however, the overall holdings of insiders (managers and employees). This is because managers may control the employee vote in return for implicit job security.

The state still controls small minority stakes in all countries. In Moldova, about a quarter (23.8\%) of the stock of privatized companies is held by the state, while Kyrgyz privatized firms have only a $5.6 \%$ residual state control. These numbers underestimate the power of the state in influencing the restructuring process of enterprises. Managers of Ukrainian and Kazak firms, for example, frequently complained that even if the state had a $5 \%$ stake in their company, the state representative on the Board of Directors could still block many decisions. In Moldova, interviewed enterprise managers complained that they were discouraged from firing workers by state-appointed directors.

Outside foreign investors still represent a minor share of the stock in the sample, the most in Kazak enterprises (6.8\%), the least in Ukrainian enterprises - less than $1 \%$. The reason is partly due to the absence of developed secondary markets in the six countries, where foreigners (and outsiders in general) could buy stocks. Stock exchanges either do not exist (Georgia and Kazakstan), 
list a small number of companies (40 in the Kyrgyz Republic, 65 in Ukraine), or have restrictions on the participation of foreign investors (Moldova and Russia). Thus the level of foreign investment in the NIS seems to be driven by cross-country differences in the legal framework and the development of secondary capital markets, rather than by industry-specific factors.

In all six countries, the changes in ownership structure between 1995 and 1997 increased insider (and in particular, managerial) ownership at the expense of state and outsider ownership. There are still wide differences across countries, with insiders owning as much as two-thirds of shares in Georgian companies, and only $37.6 \%$ in Kazak firms. State-ownership still remains nontrivial in many companies, however. The sale of these remaining shares to private investors may rapidly re-shape the current ownership structure.

Table 3

Changes in the ownership structure, \% of total (Means)

\begin{tabular}{|c|c|c|c|c|c|c|}
\hline Country & Managers & Employees & The State & $\begin{array}{l}\text { Outside } \\
\text { Local } \\
\text { Investors }\end{array}$ & $\begin{array}{l}\text { Outside } \\
\text { Foreign } \\
\text { Investors }\end{array}$ & Individuals \\
\hline \multicolumn{7}{|l|}{ Georgia } \\
\hline 1995 & 41.5 & 9.4 & 41.0 & 4.9 & 1.0 & 2.0 \\
\hline 1997 & 53.6 & 10.4 & 23.3 & 8.0 & 2.2 & 2.2 \\
\hline \multicolumn{7}{|c|}{ Kazakstan } \\
\hline 1995 & 23.1 & 10.7 & 34.8 & 23.6 & 4.4 & 3.4 \\
\hline 1997 & 29.4 & 8.2 & 16.1 & 30.2 & 6.8 & 9.3 \\
\hline \multicolumn{7}{|c|}{ Kyrgyz Republic } \\
\hline 1995 & 28.1 & 38.3 & 12.4 & 16.8 & 2.2 & 2.2 \\
\hline 1997 & 34.4 & 36.4 & 5.6 & 18.9 & 2.3 & 2.4 \\
\hline \multicolumn{7}{|l|}{ Moldova } \\
\hline 1995 & 7.2 & 21.6 & 38.6 & 24.7 & 0.3 & 7.6 \\
\hline 1997 & 18.3 & 19.7 & 23.8 & 22.6 & 2.1 & 13.5 \\
\hline \multicolumn{7}{|l|}{ Russia } \\
\hline 1995 & 25.4 & 26.0 & 23.5 & 23.4 & 1.6 & 0.1 \\
\hline 1997 & 36.3 & 23.3 & 14.7 & 21.5 & 3.8 & 0.4 \\
\hline \multicolumn{7}{|l|}{ Ukraine } \\
\hline 1995 & 14.6 & 23.6 & 42.6 & 18.9 & 0.3 & 0.2 \\
\hline 1997 & 46.2 & 15.3 & 15.4 & 17.7 & 0.9 & 4.5 \\
\hline
\end{tabular}

The shares are unweighted averages. State ownership includes property under local and municipal administrations. Outside Local Investors include investment funds. 


\section{Ownership Types and Restructuring}

\subsection{Restructuring Measures}

We define restructuring as changes in operations, interactions, and motivation towards success in a changing market environment. This definition captures the essence of the restructuring changes, some which will be forced by the behavior of other market players, while others will be pursued by management and owners. We use three complementary measures of restructuring: increases in labor productivity (sales per worker growth), assets sales, and renovations at the factory to improve working conditions. The first measure is based on accounting data and is most often used in previous empirical work (Frydman et al, 1997; Pohl et al., 1997; Estrin and Rosevear, 1998; Linz and Krueger, 1998) as it depends on both "defensive" or "passive" restructuring (reduction in excess employment), and on "active" restructuring (increase in sales volume). The measure may, however, be misleading since substantial improvements in labor productivity need not arise from "pro-active" restructuring, particularly when it is accompanied by a substantial drop in output (Ericson, 1998). Instead, labor productivity growth may simply account for a low initial level of efficiency, i.e., for the elimination of waste.

We hence use two other measures of active restructuring (asset sales and minor renovations), following Barberis et al. (1996). Both measures (along with positive real investment, changes in management, suppliers, customers, etc.) can be argued to be highly correlated with restructuring. As discrete variables, they diminish the information on restructuring across firms and are cruder than accounting measures. For example, what do different types of minor renovations reveal about the willingness for restructuring? Does it matter how much revenues the enterprise received from asset sales? Or were such sales just another form of asset stripping? These questions are difficult as managers (understandably) are not forthcoming with their answers.

In a previous version of the paper, we also used the share of barter as an indicator of restructuring. The argument made was that barter is associated with significant costs to enterprises (see, for example, Hendley et al., 1997) and a high share of barter implies efficiency losses. Linz and Krueger (1998), however, use barter as is an indicator of the ability of managers to maneuver, manipulate, and survive, by maintaining their enterprise in operations. Ericson (1998), in contrast, argues that barter involves the building of wasteful facilities to manufacture and process barter products, and is an economically inefficient activity. In the absence of a consensus on the appropriateness of this measure, we drop it from the analysis.

In the enterprise sample here, Georgian enterprises show the largest annual growth in labor productivity during 1995-97 - 19.2\% on average (Table 4). Enterprises in the Kyrguz Republic have the second highest growth $14.6 \%$, followed by enterprises in Russia, Kazakstan, and Ukraine. The least 
growth is recorded by Moldovan enterprises $-9.4 \%$. These numbers compare favorably with labor productivity growth in the initial transition period in Central and Eastern Europe, where labor productivity grew at $7 \%$ on average (Pohl et al., 1997). It is important to remember that Georgian enterprises had virtually ceased operations during the civil war in 1993-94, and the sales growth was coming from a low base. Smaller, but significant interruptions of operations had occurred in most of the other NIS sample countries.

The sale or leasing of assets (equipment, buildings) is our second measure of restructuring. Managers can use the proceeds from such sales to finance working capital. This indicator also reveals management quality: managers who refuse to sell assets in the hope of "better times" will likely cease operations altogether. The largest share of enterprises which sold assets was in the Kyrgyz Republic - a third of all enterprises either leased buildings and space or sold some assets. Interestingly, most clients came from China and Pakistan. In some NIS countries the sale of assets was either prohibited or levied with large taxes. In Georgia, the country with the least asset sales $(18.2 \%)$, enterprises paid a tax on the difference between the sale price and the price of assets (artificially bloated) during privatization. In Ukraine, some equipment was still under mobilization reserve (the enterprise had to maintain it in case of war) and could not be sold.

\section{Table 4 \\ Measures of Restructuring (unweighted averages)}

\begin{tabular}{cccc}
\hline Country & $\begin{array}{c}\text { Sales per Worker } \\
\text { Growth, p.a. 1995-97 }\end{array}$ & $\begin{array}{c}\text { Sale of Assets } \\
\text { (\% of enterprises) }\end{array}$ & $\begin{array}{c}\text { Minor Renovations } \\
(\% \text { of enterprises })\end{array}$
\end{tabular}

\begin{tabular}{lrll}
\hline Georgia & 19.2 & 18.2 & 24.2 \\
Kazahkstan & 11.4 & 24.3 & 39.2 \\
Kyrgyz Rep. & 14.6 & 33.6 & 44.2 \\
Moldova & 9.4 & 23.7 & 29.6 \\
Russia & 12.1 & 24.6 & 30.2 \\
Ukraine & 10.8 & 21.1 & 52.6
\end{tabular}

The last indicator of operational restructuring is the undertaking of minor renovations to improve working conditions at the factory. This measure is highest in Ukraine (52.6\%) and the Kyrgyz Republic (39.2\%), and lowest in Georgia (24.2\%) and Moldova (29.6\%). It is highly correlated with the sale of assets measure - the simple correlation coefficient is 0.68 for the sample as a whole. It correlates poorly with labor productivity growth - the simple correlation coefficient is 0.37 . These correlations support Ericson's argument that labor productivity need not be associated with active restructuring. 


\subsection{Regression Analysis}

In this section we study the pattern of association between different ownership structures and enterprise restructuring. Two hypotheses have been presented in the previous literature of ownership and performance (Shleifer and Vishny, 1997). The first hypothesis states that the various types of owners may have different incentives to force restructuring, and that these incentives result in different restructuring efforts. The second hypothesis states that there exists an inverse U-shaped relation between ownership concentration (by any type of owner) and corporate performance, since the controlling shareholder(s) may now pursue non-profit maximizing strategies without being accountable to the minority shareholders. Thus it is necessary to study the linear relation between ownership types and enterprise performance, as well as the non-monotonic relation between the two.

To determine the linear relation between ownership structure and enterprise restructuring, we use a multivariate regression analysis which controls for industry-specific and country-specific factors. Although two of our independent variables are discrete, we use OLS with heteroskedasticity-corrected standard errors rather than probits to make the comparisons of regressions and the interpretation of results easier. In an earlier draft, we have performed probits as well - the implied probabilities are very close to the OLS estimates.

We use as right-hand side variables the continuous ownership shares by each type of owner as reported in Table 3 . Ownership by individuals is used as the numeraire. For robustness purposes, regressions are also run where the holdings of these four types of owners are taken as discrete variables (not reported). Those show similar results and are omitted from the discussion. In alternative specifications, we also controlled for the effect of sectors, size (proxied by employment or assets), location, and access to bank financing. Those controls did not yield any consistent parameter estimates and are dropped from the analysis here. The size dummy is not significant in any specification, location in the capital city is positive and significant only for asset sales, access to bank financing is positively related to labor productivity growth. The country dummies are used to account for the unexplained variation due to differences in the legal and regulatory environment, the location of the country, and the inherited industrial mix and infrastructure. The results are reported in Table 5 for the whole sample. We choose not to interpret the magnitude of the coefficients, given the tenuous nature of the sample's representativeness. Instead, the focus is on their signs and significance.

The evidence on ownership types is not robust across the three restructuring measures, and does not explain much of the variation as only two of the fifteen coefficients are statistically significant. State ownership is always associated with less restructuring (a negative parameter estimate) but this association is never significant. Employee ownership is also associated with less restructuring in the first two regressions, but again the association is not 
significant. Managerial ownership and local outsider ownership are weakly associated with more restructuring on all three measures. Only foreign outsider ownership is significantly positively associated with enterprise restructuring, on two of the three measures. ${ }^{6}$

Sector origin is rarely significant in explaining enterprise restructuring, but sector dummies are always jointly significant. The Metals and Machinery sectors are associated with less restructuring, while the Wood and Furniture and the Food and Beverage sectors are positively associated with restructuring. This pattern is hardly surprising, since the enterprises in the light industry sectors (food, textiles, furniture) did not experience as much drop in demand as the heavy industry sectors during the transition period.

The pattern of country-dummy coefficients weakly supports the conclusion that Kyrgyz firms have restructured the most, while Georgian and Moldovan firms have restructured the least. The t-statistics on the country coefficients also suggest that as much as two-thirds of the explanatory power of the regressions depend on cross-country differences. Since we have already accounted for sector and ownership composition, the omitted variables (proxied by the country-dummies) are likely the legal reform efforts and the subsequent implementation of new laws and regulations which improve the restructuring environment.

We next divide ownership in three categories - below $10 \%$, between $10 \%$ and 30\%, and above 30\% - following on McConnell and Servaes (1990). The idea is to test whether some non-linearities exist in the relation between ownership structure and enterprise restructuring. Such non-monotonic associations are predicted by the theory but may not hold in the rapidly changing environment of enterprises in transition, where outside factors play a predominant role. Surprisingly, however, we do find some interesting patterns when we use piecewise regressions (Tables 6 and 7).

Table 5

Regression Analysis, Linear Relation

\begin{tabular}{cccc}
\hline Explanatory Variable & $\begin{array}{c}\text { Labor } \\
\text { Productivity } \\
\text { Growth }\end{array}$ & Sale of Assets & $\begin{array}{c}\text { Minor } \\
\text { Renovat }\end{array}$ \\
\hline Ownership Types & 0.02 & 0.03 & 0.01 \\
Managers & $(1.41)$ & $(1.17)$ & $(0.28)$ \\
& -0.01 & -0.00 & 0.02 \\
Employees & $(0.54)$ & $(0.32)$ & $(0.84)$ \\
& -0.03 & -0.00 & -0.02 \\
The State & $(1.37)$ & $(0.56)$ & $(1.41)$ \\
& 0.02 & 0.02 & 0.03 \\
Local Outsiders & $(1.21)$ & $(1.51)$ & $(1.34)$
\end{tabular}


Table 5: (cont'd)

\begin{tabular}{|c|c|c|c|}
\hline Explanatory Variable & $\begin{array}{l}\text { Labor } \\
\text { Productivity } \\
\text { Growth }\end{array}$ & Sale of Assets & $\begin{array}{l}\text { Minor } \\
\text { Renovations }\end{array}$ \\
\hline Foreign Outsiders & $\begin{array}{c}0.04 \\
(1.08)\end{array}$ & $\begin{array}{c}0.03 * \\
(2.11)\end{array}$ & $\begin{array}{l}0.01^{* *} \\
(1.75)\end{array}$ \\
\hline Individuals & $\begin{array}{c}0.00 \\
(0.34)\end{array}$ & $\begin{array}{l}-0.00 \\
(0.47)\end{array}$ & $\begin{array}{l}-0.00 \\
(0.85)\end{array}$ \\
\hline \multicolumn{4}{|l|}{ Industry Dummies } \\
\hline Metals & $\begin{array}{l}-0.08 \\
(0.79)\end{array}$ & $\begin{array}{l}-0.16^{*} \\
(2.18)\end{array}$ & $\begin{array}{l}-0.08^{* *} \\
(1.76)\end{array}$ \\
\hline Chemicals & $\begin{array}{c}0.29^{*} \\
(2.19)\end{array}$ & $\begin{array}{l}-0.08 \\
(1.67)\end{array}$ & $\begin{array}{l}-0.15 \\
(1.37)\end{array}$ \\
\hline Machinery & $\begin{array}{l}-0.03 \\
(0.29)\end{array}$ & $\begin{array}{l}-0.09^{*} \\
(2.38)\end{array}$ & $\begin{array}{l}-0.27^{*} \\
(3.54)\end{array}$ \\
\hline Wood and Furniture & $\begin{array}{c}0.09 \\
(0.64)\end{array}$ & $\begin{array}{c}0.24 \\
(1.24)\end{array}$ & $\begin{array}{l}0.19^{* *} \\
(1.84)\end{array}$ \\
\hline Construction Materials & $\begin{array}{l}0.26^{* *} \\
(1.76)\end{array}$ & $\begin{array}{l}-0.18 \\
(0.35)\end{array}$ & $\begin{array}{c}0.07 \\
(1.44)\end{array}$ \\
\hline Textiles and Apparel & $\begin{array}{l}-0.25^{*} \\
(1.97)\end{array}$ & $\begin{array}{c}0.28^{*} \\
(3.24)\end{array}$ & $\begin{array}{c}0.27 \\
(1.57)\end{array}$ \\
\hline Food \& Beverage & $\begin{array}{c}0.22^{*} \\
(1.99)\end{array}$ & $\begin{array}{c}0.15 \\
(0.64)\end{array}$ & $\begin{array}{c}0.28^{*} \\
(3.12)\end{array}$ \\
\hline \multicolumn{4}{|l|}{ Country Dummies } \\
\hline Georgia & $\begin{array}{c}0.25^{*} \\
(10.42)\end{array}$ & $\begin{array}{l}-0.06^{*} \\
(4.15)\end{array}$ & $\begin{array}{l}-0.08^{*} \\
(1.97)\end{array}$ \\
\hline Kazahkstan & $\begin{array}{c}0.06 \\
(0.77)\end{array}$ & $\begin{array}{c}0.02 \\
(0.45)\end{array}$ & $\begin{array}{l}0.05^{* *} \\
(1.83)\end{array}$ \\
\hline Kyrgyz Rep. & $\begin{array}{c}0.10^{*} \\
(3.64)\end{array}$ & $\begin{array}{c}0.17^{*} \\
(3.19)\end{array}$ & $\begin{array}{c}0.15^{*} \\
(4.18)\end{array}$ \\
\hline Moldova & $\begin{array}{l}-0.17 \\
(0.56)\end{array}$ & $\begin{array}{l}-0.03 \\
(1.05)\end{array}$ & $\begin{array}{l}-0.01 \\
(0.66)\end{array}$ \\
\hline Ukraine & $\begin{array}{l}-0.06 \\
(0.86)\end{array}$ & $\begin{array}{c}0.01 \\
(0.68)\end{array}$ & $\begin{array}{c}0.19^{*} \\
(6.78)\end{array}$ \\
\hline Adjusted $R^{2}$ & 0.21 & 0.19 & 0.27 \\
\hline
\end{tabular}

Note: The numeraire for industries is Pharmaceuticals; the numeraire for countries is Russia. Labor Productivity Growth is defined as the log-difference is the inflationadjusted value of total sales in 1997 and 1995. Sale of Assets is a discrete variable equal to 1 if the company reported sales in the $1995-97$ period, 0 otherwise. Minor Renovations is also a discrete variable equal to 1 if the general manager reported some improvements to the buildings, 0 otherwise. Absolute values of t-stats are reported in parentheses. A constant term is included in all regressions. The number of observations is 960 . Significant at the $5 \%$ level; ** Significant at the $10 \%$ level. 


\section{Table 6}

Ownership Structure and Restructuring, Piecewise Relation (Labor Productivity Growth)

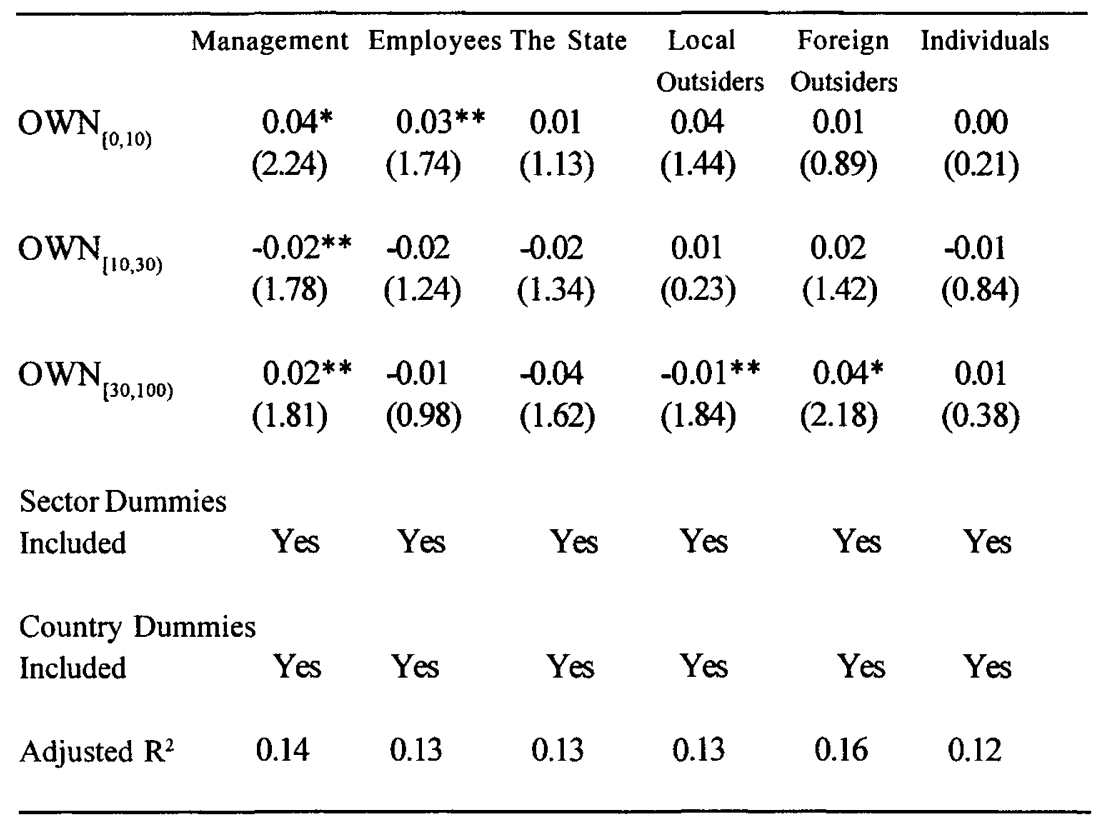

Note: Absolute values of $t$-stats are reported in parentheses. A constant term is included in all regressions. The number of observations is 960 . $^{*}$ Significant at the $5 \%$ level; ${ }^{* *}$ Significant at the $10 \%$ level.

We find that foreign ownership is always positively associated with labor productivity growth, but this association is significant only if foreigners own more than $30 \%$ of the company (Table 6). In contrast, the relation between manager ownership and productivity growth in non-monotonic, positive at low (below 10\%) or high (above 30\%) stakes, but negative at intermediate (between $10 \%$ and $30 \%$ ) levels. We also show that ownership by outside local investors is negatively correlated with productivity growth for high (above $30 \%$ ) ownership stakes. Finally, employee ownership is beneficial to restructuring at low ownership levels, but becomes insignificant at higher levels. The ownership by individuals is not a significant determinant of labor productivity growth at any concentration. Given the small number of observations for the last two ownership types, these results may not be representative.

We next regress asset sales on the same set of explanatory variables and find that some of the patterns in the relation between labor productivity growth and ownership structure are present here too. Foreign ownership is again positively associated with labor productivity growth, and this association is significant if foreigners own more than $10 \%$ of the company (Table 7 ). The 
relation between manager ownership and asset sales is also positive but significant only for low (below 10\%) or high (above 30\%) stakes. Ownership by employees, the state, outside local investors, and individuals is not correlated with asset sales at any concentration. ${ }^{7}$

Table 7

Ownership Structure and Restructuring, Piecewise Relation (Sale of Assets)

\begin{tabular}{|c|c|c|c|c|c|c|}
\hline & Management & Employee & The State & $\begin{array}{l}\text { Local } \\
\text { Outsiders }\end{array}$ & Foreign & Individuals \\
\hline $\mathrm{OWN}_{[0,10)}$ & $\begin{array}{l}0.03 * * \\
(1.89)\end{array}$ & $\begin{array}{l}-0.01 \\
(0.82)\end{array}$ & $\begin{array}{c}0.01 \\
(0.66)\end{array}$ & $\begin{array}{c}0.00 \\
(0.51)\end{array}$ & $\begin{array}{c}0.01 \\
(1.01)\end{array}$ & $\begin{array}{c}0.01 \\
(0.84)\end{array}$ \\
\hline $\mathrm{OWN}_{[10,30)}$ & $\begin{array}{c}0.02 \\
(1.41)\end{array}$ & $\begin{array}{l}-0.02 \\
(1.17)\end{array}$ & $\begin{array}{l}-0.01 \\
(1.10)\end{array}$ & $\begin{array}{c}0.01 \\
(1.12)\end{array}$ & $\begin{array}{l}0.03 * * \\
(1.92)\end{array}$ & $\begin{array}{l}-0.02 \\
(0.66)\end{array}$ \\
\hline $\mathrm{OWN}_{[30,100)}$ & $\begin{array}{l}0.03^{*} \\
(2.58)\end{array}$ & $\begin{array}{l}-0.00 \\
(0.43)\end{array}$ & $\begin{array}{l}-0.01 \\
(1.37)\end{array}$ & $\begin{array}{l}-0.03 \\
(1.08)\end{array}$ & $\begin{array}{c}0.03^{*} \\
(3.11)\end{array}$ & $\begin{array}{l}-0.01 \\
(1.42)\end{array}$ \\
\hline $\begin{array}{l}\text { Sector Dumn } \\
\text { Included }\end{array}$ & nies & Yes & Yes & Yes & Yes & Yes \\
\hline $\begin{array}{l}\text { Country Dur } \\
\text { Included }\end{array}$ & $\begin{array}{l}\text { nmies } \\
\\
\\
\text { Yes }\end{array}$ & Yes & Yes & Yes & Yes & Yes \\
\hline Adjusted $\mathrm{R}^{2}$ & 0.10 & 0.09 & 0.09 & 0.09 & 0.11 & 0.09 \\
\hline
\end{tabular}

Note: Absolute values of t-stats are reported in parentheses. A constant term is included in all regressions. The number of observations is $960{ }^{*}$ Significant at the $5 \%$ level; ** Significant at the $10 \%$ level.

The results from Table 6 and 7 suggest that increasing ownership by managers is beneficial to restructuring in low and high ownership ranges, but is not beneficial in the intermediate range. This finding is consistent with the studies of corporate governance issues in the US outlined in Section 2. It is a result of the trade-off between manager entrenchment and incentive alignment. Foreign ownership is generally beneficial, but becomes significantly so only at high ownership ranges. There is no evidence for robust relation between other ownership types and enterprise restructuring. 


\section{Conclusions}

We have examined the relation between ownership structure and enterprise restructuring for a cross-section of privatized manufacturing firms in six NIS countries. The linear analysis indicates no significant influence of ownership on the three restructuring measures. In contrast, the non-linear analysis shows some significant relations between different types of ownership and enterprise restructuring. These findings are consistent with some of the theoretical models of corporate governance in mature economies and suggest that the future empirical work on enterprise behavior during transition needs to distinguish the effects of ownership at different concentration levels.

We also find evidence of significant differences in ownership structure across countries. These differences are highly correlated with the particular mix of privatization methods followed, indicative of hysteresis in the ownership transformation process. Countries which pursued management buy-outs as the prevalent privatization method ended up having larger ownership stakes in the hands of managers, and this concentration of control increased relative to countries which opted for mass privatization.

\section{Notes}

1 Those include the Czech Republic, Estonia, Hungary, Latvia, Lithuania, Poland, the Slovak Republic, and Slovenia. The two most comprehensive studies are Frydman et al, (1997) and Pohl et al, (1997).

2 There is, however, a large number of empirical studies on Russian enterprises. See Earle and Estrin (1997) and Linz and Krueger (1998) for reviews of the literature. Estrin and Rosevear (1998) investigates the relation between ownership structure and enterprise restructuring in Ukraine.

${ }^{3}$ A theoretical discussion on the effect of the collapse of the Soviet Union on economic relations between enterprises is given in Blanchard and Kremer (1997).

${ }^{4}$ The distribution of enterprises by regions is as follows: Georgia (Tbilisi - 101 firms, Kutaisi - 14, Rustavi - 7, Gori - 7); Kazakstan (Almaty - 51, Karagandi - 11); Kyrgyz Republic (Bishkek - 33, Osh - 14, Jalal-Abad - 17, Talas - 4, Issyk-Kul - 11); Moldova (Kishinev-101, Balti-14, Soroca-12, Drochia-4, Nisporeni-3, Dobrugea -3); Russia (Altai-95, Voronezh-96, Moscow-179, Novosibirsk-43, Saratov-92, Yekaterininburg - 177); Ukraine ( Kiev - 19, Lviv - 16, Dnepropetrovsk - 14).

${ }^{5}$ The eight largest investment funds in Moldova in 1997 owned less than 25 percent of equity in 62 percent of companies from their portfolios; between 25 and 50 percent of the equity in 14 percent of companies; controlling packages of more than 50 percent of shares in 24 percent of companies.

${ }^{6} \mathrm{We}$ also run the regressions on Russian firms only. The effects of ownership structure reveal similar patterns, with foreign outsider variables losing their significance.

7 We also use the minor renovations measure in the piecewise-linear analysis. The results are qualitatively similar to the results in Table 7 and are not reported. 


\section{References}

Barberis, Nicholas, et al. (1996). "How Does Privatization Work? Evidence from Russian Shops,” Journal of Political Economy, 104: 764-790.

Berle, Adolf and Gardiner Means. (1933). The Modern Corporation and Private Property, New York, MacMillan.

Blanchard, Olivier and Michael Kremer. (1997). "Disorganization," Quarterly Journal of Economics, 105: 1091-1126.

Blasi, Joseph, and Douglas Kruse. (1995). "Employee Ownership, Employee Attitudes, and Firm Performance," NBER Working Paper 5277, National Bureau of Economic Research, Cambridge, Massachusetts.

Blasi, Joseph, Michael Conte, and Douglas Kruse. (1996). "Employee Stock Ownership and Corporate Performance among Public Companies," Industrial and Labor Relations Review, 50: 60-79.

Carlin, Wendy, John van Reenen, and Toby Wolfe. (1995). "Enterprise Restructuring in Early Transition: the case study evidence from Central and Eastern Europe," Economics of Transition, 3: 427-458.

Coase, Ronald. (1988). "The Theory of the Firm?" in Coase. R. "The Firm, the Market, and the Law," University of Chicago Press, Chicago and London, pp. 33-55.

Demsetz, Harold and Kenneth Lehn. (1985). The Structure of Ownership: Causes and Consequences, Journal of Political Economy 93, 1155-77.

Earle, John and Saul Estrin. (1997). "After Voucher Privatization: The Structure of Corporate Ownership in Russian Manufacturing Industry," SITE Working Paper 120, Stockholm Institute of Transition Economics, Stockholm, Sweden.

EBRD. (1997). Transition Report 1997. London.

Ericson, Richard. (1998). "Restructuring in Transition: Concept and Measurement," Comparative Economic Studies, 40: 103-108.

Estrin, Saul, and Adam Rosevear. (1998). "Ownership and Company Restructuring in Ukraine," European Economic Review, forthcoming.

Friend I., and L. Lang, (1988). "An Empirical Test of the Impact of Managerial Self Interest on Corporate Capital Structure," Journal of Finance 43, 271-281.

Frydman, Roman, Cheryl Gray, and Andrej Rapaczynski. (1997). "Private Ownership and Corporate Performance: Some Lessons from Transition Economies," New York University Working Paper 9827, New York.

Hendley, Kathryn, Barry Ickes, and Randi Ryterman. (1997). “Observation on the Use 
of Law by Russian Enterprises," Post-Soviet Affairs, 13: 19-41.

Jensen, Michael. (1993). "The Modern Industrial Revolution, Exit, and the Failure of Internal Control Systems," Journal of Finance, 48: 831-880.

Johnson, W. Bruce, Robert P. Magee, Nandu J. Nagarajan, and Harry Newman. (1985). "An Analysis of the Stock Price Reaction to Sudden Executive Deaths: Implication for the Managerial Labor Market," Journal of Accounting and Economics, 7:151-174.

Konings, Jozef. (1998). "Firm Growth and Ownership Transition," Economic Letters, forthcoming.

Linz, Susan, and Gary Krueger. (1998). "Enterprise Restructuring in Russia's Transition Economy: Formal and Informal Mechanisms," Comparative Economic Studies, 40: 552.

Malatesta, Paul and Ralph Walkling. (1988). "Poison Pill Securities: Stockholder Wealth, Profitability, and Ownership Structure, “Journal of Financial Economics, 20: 347-376.

McConnell, John and Henri Servaes. (1990). “Additional Evidence on Equity Ownership and Corporate Value," Journal of Financial Economics, 27: 595-612.

Megginson, William, et al. (1994). "The Financial and Operating Performance of Newly Privatized Firms: An International Empirical Analysis," Journal of Finance, 49: 403452.

Morck, R., A. Shleifer and R. Vishny. (1988). "Management Ownership and Market Valuation: An Empirical Analysis," Journal of Financial Economics 20, 293-315.

Pinto, Brian, Marek Belka, and Stefan Krajewski. (1993). "Transforming State Enterprises in Poland: Evidence on Adjustment by Manufacturing Firms, " Brookings Papers on Economic Activity, 1: 213-270.

Pohl, Gerhard, et al. (1997). "Privatization and Restructuring in Central and Eastern Europe: Evidence and Policy Options," Technical Paper 368, The World Bank, Washington DC.

Roll, Richard. (1986). "The Hubris Hypothesis of Corporate Takeovers, "Journal of Business, 59: 197-216.

Shleifer, Andrei and Robert Vishny. (1994). "Politicians and Firms," Quarterly Journal of Economics, 104: 995-1025.

Shleifer, Andrei and Robert Vishny. (1986) "Large Shareholders and Corporate Control," Journal of Political Economy, 94: 461-488.

Shleifer, Andrei and Robert Vishny (1997). "A Survey of Corporate Governance," Journal of Finance, 52: 737-783. 
Smith, Stephen, Beom-Cheol Cin, and Milan Vodopivec. (1997). "Privatization Incidence, Ownership Forms, and Firm Performance: Evidence from Slovenia, "Journal of Comparative Economics, 25: 158-179.

Walkling, Raiph and Michael Long. (1984). "Agency Theory, Managerial Welfare, and Takeover Bid Resistance," Rand Journal of Economics, 15: 54-68.

World Bank. (1994). The East Asian Miracle, World Bank and Oxford University Press, Washington DC. 